\title{
Developing and Strengthening Networks to Promote Resilience After Disasters ${ }^{1}$
}

\author{
Angela B. Lindsey, Samantha Goldenberg, and Cassie Wandersee ${ }^{2}$
}

\section{Healthy Gulf, Healthy Communities Project}

The Healthy Gulf, Healthy Communities (HGHC) project, funded by the National Institute of Environmental Health Sciences (NIEHS), works with communities impacted by the 2010 Deepwater Horizon oil spill to conduct research on resiliency and seafood safety. The aftermath of the DWH oil spill prompted a UF/IFAS-led team of researchers to study the physiological, psychological, and sociological effects of the disaster in order to help communities recover and prepare for future potential disasters.

\section{HGHC Series Overview}

The HGHC EDIS Series includes thirteen publications that focus on the work of the community outreach and dissemination team, including community engagement, outreach, and research result dissemination. This is the first publication in the series and focuses on developing and strengthening networks before they are challenged to promote resilience in and after a disaster.

\section{Introduction}

When a disaster occurs, nonprofit organizations often collaborate with the private and public sector through partnerships, alliances, and coalitions, which work together to promote resiliency within the affected community (Simo \& Bies, 2007). Resiliency is the ability to return to the state of equilibrium that was in place before the disaster occurred (Kim \& Marcouiller, 2016). The community has social, economic, environmental, institutional, and infrastructural factors that contribute to its resilience during a natural disaster (Kim \& Marcouiller, 2016). Communities that have greater economic stability and social capital are more likely to have the resources needed to minimize loss due to the disaster. Social capital refers to social norms and networks that encourage collaboration and action (Aldrich \& Meyer, 2014). The social cohesion and connectedness that create resiliency are formed in social networks, faithbased organizations, nonprofit organizations, and the like. Social networks, social support, and social inclusion are community strengths that are increased when collaborating with nonprofit organizations during disaster recovery (Berkes \& Ross, 2013). Taking advantage of the local social capital, as well as the organizations that volunteer to help, will create a more efficient and effective recovery.

\section{Cultural Resilience}
Colten, Hay, and Giancarlo (2012) identified several behaviors of Louisiana's coastal communities that enable them to endure repeated natural and manmade disasters. The practices of resilient coastal communities include

1. This document is FCS3346, one of a series of the Department of Family, Youth and Community Sciences, UF/IFAS Extension. Original publication date April 2018. Visit the EDIS website at http://edis.ifas.ufl.edu.

2. Angela B. Lindsey, assistant professor, Department of Family, Youth and Community Sciences, UF/IFAS Center for Public Issues Education in Agriculture and Natural Resources (PIE Center); Samantha Goldenberg, graduate student, Department of Family, Youth and Community Sciences; and Cassie Wandersee, research assistant, Department of Communications and Agricultural Education, Center for Rural Enterprise Engagement, Kansas State University; UF/IFAS Extension, Gainesville, FL 32611.

The Institute of Food and Agricultural Sciences (IFAS) is an Equal Opportunity Institution authorized to provide research, educational information and other services only to individuals and institutions that function with non-discrimination with respect to race, creed, color, religion, age, disability, sex, sexual orientation, marital status, national origin, political opinions or affiliations. For more information on obtaining other UF/IFAS Extension publications, contact your county's UF/IFAS Extension office. 
pursuit of natural resources in other areas, a shift in natural resources collection, drawing on family and social networks to respond to the disaster, and seeking economic relief through existing programs and/or lawsuits (Colten, 2012). Clarke and Mayer (2012) build upon the work of Colten et al. (2012) by further defining cultural resilience as "the capacity of communities to mobilize cultural resources in response to external crises and threat, which in turn shapes individual and community actions related to the recovery process." The application of cultural resiliency knowledge has been shown to positively impact communities during a disaster. It is important to understand the broader cultural context a disaster takes place in and to shape response and recovery efforts around that understanding (Clarke \& Mayer, 2017). Strong cultural resilience within the community typically means individuals in the affected community can collectively work to overcome the effects of the disaster more smoothly than those who are not a part of the community.

\section{Examples of Community Resilience}

Apalachicola, FL is a small coastal town that is highly dependent on the Gulf of Mexico for marine resources including the fishing and oyster industries. Apalachicola is more prone to natural disasters, frequently experiencing the impacts of hurricanes. The repeated exposure to major natural disasters has increased community resilience through collective memory and the persistence of perseverance in recovery efforts. Clarke and Mayer (2017) found three components of cultural resiliency in Apalachicola including place, heritage, and moral identity. Place attachment was a strong factor in creating community resilience. Residents of Apalachicola feel they live somewhere unique and beautiful, and as a result have a desire to protect their community (Clarke \& Mayer, 2017). Heritage is another component that lends to the strong sense of community resiliency in Apalachicola. Residents indicated their respect for tradition, valuation of local knowledge, preference for the area's simplicity, and a preference for hands-on methods traditional in the relatively insular community as important aspects of their heritage (Clarke \& Mayer, 2017). Moral identity is the third and final aspect residents of Apalachicola identified as being imperative to their community's resilience. Moral identity in Apalachicola is tied to community and individual values. A person's notion of self includes how that person fits into his or her community (Clarke \& Mayer, 2017). Moral identity is marked by self-reliance, individualism, and hard work, as well as the shared and enforced value system of the community (Clarke \& Mayer, 2017).
Cedar Key, FL is a small community on the Gulf Coast of Florida that also experienced the devastating effects of the DWH oil spill. Cedar Key is the dominant clam production area on Florida's northwest coast, with over $80 \%$ of the industry housed in the 150 small-scale clam operations owned and operated by local farmers who live and work in the area. The DWH oil spill caused significant loss of jobs and income as it impacted the clamming industry (Lindsey et al., 2014). Like the residents of Apalachicola, Cedar Key residents, industry members, and emergency managers came together in the face of the man-made disaster to determine the best course of action and to prepare for the worst-case scenario. Perhaps the largest impact to the community was the drop in consumer demand for clams with over $41 \%$ of consumers unwilling to buy Gulf seafood (Lindsey et al., 2014). The community of Cedar Key viewed the DWH oil spill as a learning opportunity and developed action plans to address seafood harvest reopening, public communication, and training programs. Ultimately, the resiliency of the community provided the needed foundation for disaster response and the development of future plans should another disaster occur.

\section{Proactive Steps before a Disaster}

The establishment of disaster recovery plans can lead to more resilient communities with community members that have a vested interest in the plan and are involved in the development process (Berke \& Campanella, 2006). Disaster recovery plans guide short-range emergency and rehabilitation action and long-range redevelopment decisions (Berke \& Campanella, 2006). Residents should be involved and consulted at all phases in the creation of the disaster recovery plan; their involvement creates a knowledgeable constituency that is more likely to support recovery efforts after a disaster occurs. Disaster recovery planning can greatly benefit from an understanding and utilization of community resilience values. By optimizing the existing social networks and sense of place attachment, disaster recovery planners can fundamentally involve community residents. Along with the involvement of community members, collaboration with networks outside of the community, including state and federal organizations, brings various individuals and perspectives into the planning and decision-making process. Collaboration between community residents and institutions can lead to new, creative solutions and increased resiliency that may not have developed if those residents and institutions worked independently of each other (Committee on Private-Public Sector Collaboration to Enhance Community Disaster, Geographical Science, \& National Research, 2010). Organizations can work to build community networks before a disaster occurs through local 
and regional formalized organizations including chambers of commerce, Rotary clubs, professional organizations, etc. In addition, when developing disaster preparedness plans, plan developers should reach out to their local Emergency Operations Center (EOC) to explore resources and possible partnerships. Partnerships with local EOCs will provide organizations with the ability to give emergency support in areas that need it, such as pre- and post- disaster trainings, helping local businesses, and getting people back to work as quickly as possible. Trusting relationships between everyone involved are central to building resiliency.

Organizations should prepare a disaster plan and have a continuation of operations plan (COOP) to ensure an efficient recovery process. Several organizations include disaster plans and templates including Extension Disaster Education Network (EDEN) at eden.lsu.edu and FEMA at fema.gov. In addition, organizations should look to groups within their area who are often the first to provide services in assistance following a disaster.

\section{References}

Aldrich, D. P., \& Meyer, M. A. (2014). Social capital and community resilience. American Behavioral Scientist, 59(2), 254-269. doi:10.1177/0002764214550299

Berke, P. R., \& Campanella, T. J. (2006). Planning for post disaster resiliency. The Annals of the American Academy of Political and Social Science, 604, 192-207. doi: 10.1177/0002716205285533

Berkes, F., \& Ross, H. (2013). Community resilience: Toward an integrated approach. Society \& Natural Resources, 26(1), 5-20. doi:10.1080/08941920.2012.736605

Clarke, H. E., \& Mayer, B. (2017). Community recovery following the Deepwater Horizon oil spill: Toward a theory of cultural resilience. Society \& Natural Resources, 30(2), 129-144. doi:10.1080/08941920.2016.1185556

Colten, C. E., Hay, J., \& Giancarlo, A. (2012). Community resilience and oil spills in coastal Louisiana. Ecology and Society 17(3), 1-10. doi:10.5751/es-05047-170305
Committee on Private-Public Sector Collaboration to Enhance Community Disaster Resilience, Geographical Science Committee, and National Research Council. (2010). Private-Public Sector Collaboration to Enhance Community Disaster Resilience: A Workshop Report. The National Academies Press. Washington, DC. Retrieved from: https:// ebookcentral.proquest.com/lib/ufl/detail.action?docID= $3378598 \&$ query $=$ Private-Public\%20Sector\%20Collaboration\%20to\%20Enhance\%20Community\%20Disaster\%20 Resilience\%20:\%20A\%20Workshop\%20Report

Kim, H., \& Marcouiller, D. W. (2016). Natural disaster response, community resilience, and economic capacity: A case study of Coastal Florida. Society \& Natural Resources, 29(8), 981-997. doi:10.1080/08941920.2015.1080336

Lindsey, A. B., Irani, T. A., Belva, N., Bernheim, L., Boyd, T., Gorham, L., Johnson, J., Jones, J., \& Rodriguez, S. (2014). Stories of Strength: Community Organizations' Stories of Resiliency and Growth Following the 2010 Deepwater Horizon oil spill.

Simo, G., \& Bies, A. L. (2007). The Role of Nonprofits in Disaster Response: An Expanded Model of Cross-Sector Collaboration. Public Administration Review, 67, 125-142. doi:10.1111/j.1540-6210.2007.00821.x 